Provided for non-commercial research and education use. Not for reproduction, distribution or commercial use.

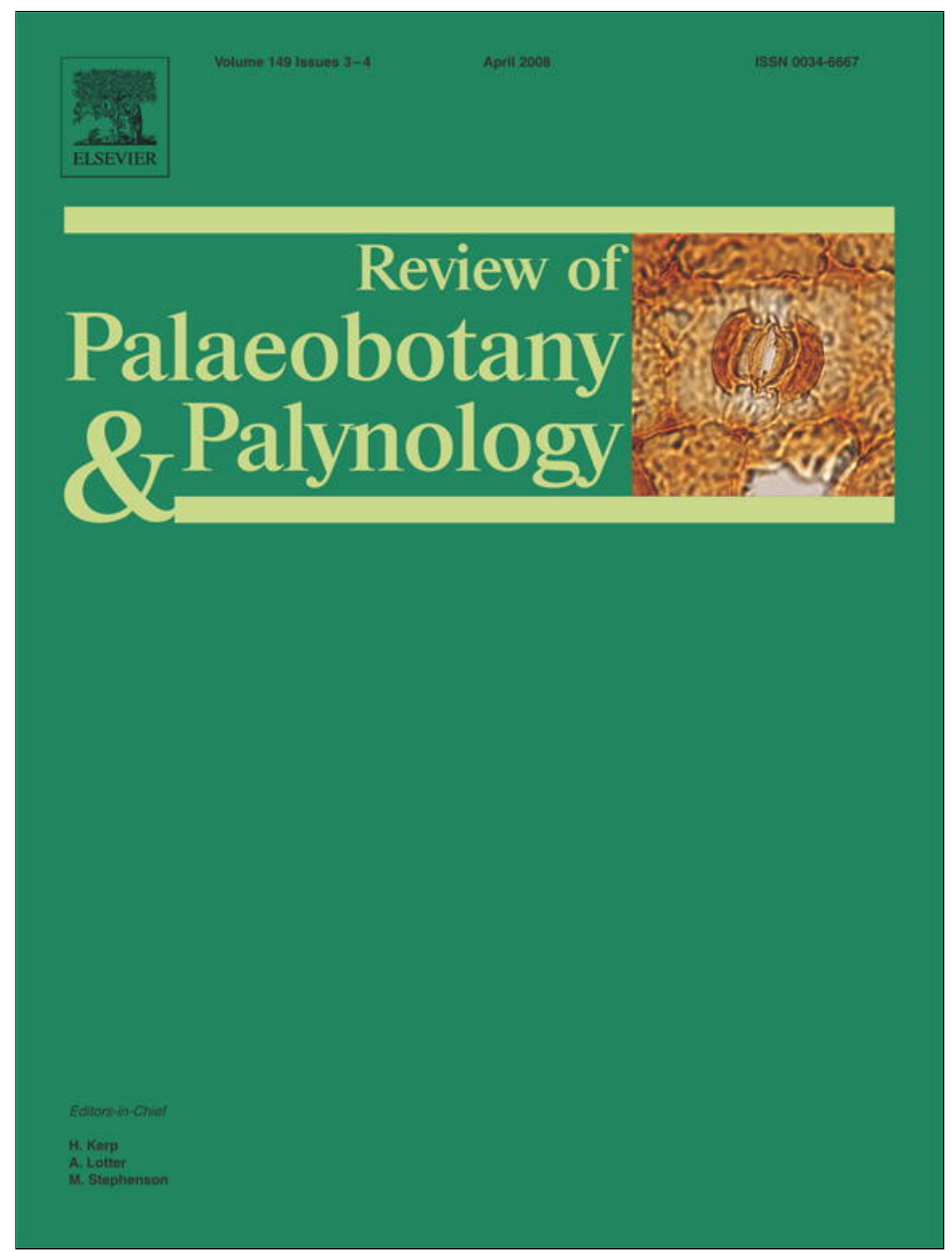

This article appeared in a journal published by Elsevier. The attached copy is furnished to the author for internal non-commercial research and education use, including for instruction at the authors institution and sharing with colleagues.

Other uses, including reproduction and distribution, or selling or licensing copies, or posting to personal, institutional or third party websites are prohibited.

In most cases authors are permitted to post their version of the article (e.g. in Word or Tex form) to their personal website or institutional repository. Authors requiring further information regarding Elsevier's archiving and manuscript policies are encouraged to visit:

http://www.elsevier.com/copyright 


\title{
Comparative pollen morphology and ultrastructure of Mentheae subtribe Nepetinae (Lamiaceae)
}

\author{
Hye-Kyoung Moon ${ }^{a, *}$, Stefan Vinckier ${ }^{\text {a,b }}$, Erik Smets ${ }^{\text {a,c }}$, Suzy Huysmans ${ }^{\text {a }}$ \\ ${ }^{a}$ Laboratory of Plant Systematics, Institute of Botany and Microbiology, K.U. Leuven, Kasteelpark Arenberg 31, P.O. Box 2437, BE-3001 Leuven, Belgium \\ ${ }^{\mathrm{b}}$ Center for Transgene Technology and Gene therapy, Flanders Institute for Biotechnology (VIB-3), K.U. Leuven, campus Gasthuisberg, \\ Herestraat 49, BE-3000 Leuven, Belgium \\ c National Herbarium of The Netherlands, Leiden University Branch, P.O. Box 9514, NL-2300 RA Leiden, The Netherlands
}

Received 6 September 2007; received in revised form 22 November 2007; accepted 1 December 2007

Available online 15 December 2007

\begin{abstract}
This study provides new pollen data of 52 representative species belonging to all 12 genera in the currently classification of the subtribe Nepetinae, and considers the possible presence of orbicules for the first time. Pollen morphology and ultrastructure were investigated with light, scanning electron and transmission electron microscopy. Nepetinae pollen is small to large ( $P=16-65 \mu \mathrm{m}, E=17-53 \mu \mathrm{m})$, oblate to prolate $(P / E=0.7-1.6)$ in shape and mostly hexacolpate (sometimes octocolpate). The exine stratification in all taxa studied is similar and characterized by unbranched columellae and a continuous, granular endexine. Sexine ornamentation in the Nepetinae is bireticulate, microreticulate or perforate. In perforate and microreticulate pattern a tendency towards a bireticulum could be recognized due to trace of secondary tectal connections. The bireticulate pattern is most common with variations of primary muri and secondary reticulum. In Hymenocrater and Schizonepeta the observed variation of sexine ornamentation is particularly valuable at the generic level. Pollen data support Lophanthus and Nepeta as very closely allied and Lallemantia is clearly distinct from Dracocephalum. The formerly suggested infrageneric relationships within Dracocephalum and Nepeta are only partly corroborated by palynological characters. Orbicules are absent in the Nepetinae.
\end{abstract}

(C) 2007 Elsevier B.V. All rights reserved.

Keywords: Nepetoideae; orbicules; palynology; Nepetinae; sexine ornamentation; ultrastructure

\section{Introduction}

Pollen of the Lamiaceae has been intensively studied since Erdtman (1945) suggested a division of the family into two subfamilies based on aperture number and number of nuclei in the mature pollen grains (Lamioideae: tricolpate and bi-nucleate pollen, Nepetoideae: hexacolpate and tri-nucleate pollen). However, the tribe Mentheae (Nepetoideae), which includes nearly one fourth in all taxa within the Lamiaceae taxa, is still poorly known from a palynological point of view. In an attempt to fill this knowledge gap, we have presented a detailed pollen study of subtribe Salviinae (Mentheae), showing that variations of sexine ornamentation in the pollen characters are phylogen-

\footnotetext{
* Corresponding author. Tel.: +32 1632 1535; fax: +32 16321955 .

E-mail address: HyeKyoung.Moon@bio.kuleuven.be (H.-K. Moon).
}

etically informative (Moon et al., in press). The present study aims to further elucidate the palynological diversity within the tribe Mentheae, focusing on the subtribe Nepetinae sensu Harley et al. (2004). The Nepetinae differs from the two other subtribes in Mentheae, Salviinae and Menthinae in the length of the posterior pair of stamens and the number of calyx nerves (Wagstaff, 1992). Nepetinae sensu Harley et al. (2004) consists of 12 genera (ca. 350 species) distributed over large parts of Eurasia and North America (Harley et al., 2004).

Nepeta is the largest (ca. 200 sp.) and economically most important genus in the Nepetinae. It can be subdivided into several sections and subsections by habit, leaf morphology, inflorescence, calyx and corolla structure, and nutlet characters (Bentham, 1848; Briquet, 1897; Pojarkova, 1954; Budantsev, 1993a; Budantsev and Lobova, 1997). Based on phylogenetic analysis of molecular data, Jamzad et al. (2003) concluded that Nepeta is monophyletic but also that previous infrageneric 
Table 1

Overview of palynological characters of species studied within Nepetinae based on acetolysed pollen grains

\begin{tabular}{|c|c|c|c|c|c|c|c|c|c|c|c|c|c|c|}
\hline \multirow[t]{2}{*}{ Species } & \multirow[t]{2}{*}{$\mathrm{T}$} & \multirow[t]{2}{*}{$\mathrm{P}(\mu \mathrm{m})$} & \multirow[t]{2}{*}{$\mathrm{E}(\mu \mathrm{m})$} & \multicolumn{7}{|c|}{ Shape } & \multirow[t]{2}{*}{$\mathrm{AI}$} & \multirow[t]{2}{*}{$\mathrm{CL}(\mu \mathrm{m})$} & \multirow[t]{2}{*}{ Exine $(\mu \mathrm{m})$} & \multirow[t]{2}{*}{ SE } \\
\hline & & & & $\mathrm{O}$ & So & Os & $\mathrm{S}$ & Ps & $\mathrm{Sp}$ & $\mathrm{P}$ & & & & \\
\hline
\end{tabular}

\section{Agastache J.Clayton ex Gronov.}

A. palmeri

A. scrophulariifolia

A. urticifolia

A. urticifolia

A. urticifolia

A
A
A $33-44.2-57.4-42$

A $32-37.6-41$

A $30-36.5-45$

$30-36.0-41$

$30-33.1-37$

26-27.6-29

C 19-20.7-22

$31-35.8-41$

23-24.5-26
A $\quad 43-44.8-48 \quad 32-36.2-43$

A $49-52.2-57$

A $47-54.6-60$

A $33-37.5-42$

A $28-31.7-38$

A $35-39.1-41$

A $34-39.4-42$

A $42-49.1-61$

A 39-41.6-45

A $39-42.0-45$

A 40-42.4-45

C 29-30.4-31

A $41-49.2-55$

A 31-35.1-39

A $32-37.8-46$ 40-44.0-52

28-32.9-41

22-24.7-29

$32-35.0-42$

$30-33.5-37$

$38-45.0-53$

30-35.2-38

$33-38.2-45$

30-33.4-37

24-28.6-34

31-35.4-43

29-31.7-34

29-37.1-45

$\begin{array}{ll}- & - \\ - & - \\ - & - \\ - & - \\ + & +\end{array}$

$\begin{array}{lllll}- & - & + & ++ & + \\ \pm & \pm & ++ & + & - \\ - & - & - & + & ++ \\ - & - & \pm & ++ & + \\ ++ & - & - & - & -\end{array}$

$0.12-0.22$

$0.16-0.21$

$0.12-0.15$

$0.12-0.16$
$26-33.7-43$ 25-27.6-31 27-29.1-34

24-30.4-37

16-17.1-18
$1.2-1.5$

$1.2-2.1$

$1.1-1.2$

$1.0-1.4$

/
III-e III III-e III-e III-e III-d I-a I-a I-a I-a I-a III-d III-d I-b I-a I-b I-b I-b III-a

I-b

Drephanocaryum Pojark.

Drepanocaryum sewerzowii

Drepanocaryum sewerzowii

C 16-16.8-17 - $\pm \quad++ \pm+$ $\begin{array}{ll}++ & \pm \\ ++ & +\end{array}$
$26-28.6$

20-23.5-28

27-29.8-32

$27-31.3-35$

$27-31.2-35$

28-33.1-38

30-32.9-35

24-26.4-29

29-36.7-42

$0.08-0.16 \quad 25-28.3-32$

$0.16-0.25$

28-32.7-38
0.9-1.0

$0.9-1.1$

Glechoma L.

Glechoma hederacea

Glechoma hederacea

C $22-25.2-30$

30-35.2-46 - \pm

$++\quad+$

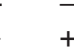

$+$

$0.12-0.20$

30-34.1-39

17-21.0-25

$0.9-1.2$

Hymenocrater Fisch. \& C.A.Mey.

Hymenocrater bituminosus

C 27-29.6-32

26-28.4-30

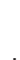

Hymenocrater longiflorus

A $49-53.1-59$

$40-44.2-50$

Lallemantia Fisch. \& C.A.Mey.

Lallemantia peltata

Lallemantia peltata

Lallemantia royleana

Lallemantia royleana

A 26-27.7-30

24-27.1-29

$-\quad-$

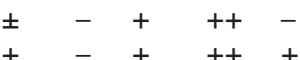

$0.11-0.16$

$22-23.2-25$

40-44.1-49 1.5-1.7

I-c

I-c

Lophanthus Adans.

Lophanthus chinensis

Lophanthus laxiflorus

Lophanthus tschimganicus

Lophanthus tschimganicus

C 16-18.0-19

$\begin{array}{lllllll}- & - & ++ & - & ++ & \pm & - \\ + & ++ & - & - & - & - & - \\ - & - & ++ & + & ++ & + & - \\ \pm & + & ++ & - & - & - & -\end{array}$

\title{
/
}

$0.17-0.21$

21-22.9-25

14-15.4-16

22-23.6-27

C 16-17.3-19

23-27.1-29

20-20.5-21

0.14-0.23

11-13.7-16

$1.1-1.4$

I-b

I-b

III-e

III-e

\begin{abstract}
A $35-41.4-51$
A 26-28.4-32

A 31-34.6-38

C 21-24.3-26
\end{abstract}

$30-35.4-40$

25-28.4-34 - -

29-33.0-39

17-19.2-21

$-$

$+$

$\begin{array}{ll}- & - \\ + & + \\ ++ & \pm \\ - & -\end{array}$

$+$

$\begin{array}{ll}++ & \pm \\ \pm & - \\ + & - \\ + & ++\end{array}$

$0.12-0.23$

30-34.6-38

$20-21.4-25$

$0.8-1.1$

$0.14-0.17$

24-28.1-31 1.5-2.1

III-c

III-e

III-b

III-b

Marmoritis Benth.

Marmoritis rotundifolia

C $28-30.6-36 \quad 30-31.3-33$ -

$++\quad+\quad+$

$-$

$0.13-0.18$

$23-26.6-31$

III-e

\section{Meehania Britton}

Meehania urticifolia

Meehania urticifolia

A $51-57.8-65 \quad 38-44.1-53 \quad-$

$\begin{array}{llllll}- & - & + & ++ & +\end{array}$

Nepeta L.

$N$. assurgens

$N$. cataria

N. cataria

N. cephalote

A 25-28.9-33

A 27-29.4-32

25-27.5-3

26-29.5-33

C 21-23.2-25

15-20.9-27

C 18-21.0-25

22-23.0-25

40-45.9-55 1.2-1.5

25-34.4-42

III-e

III-e 
Table 1 (continued)

\begin{tabular}{|c|c|c|c|c|c|c|c|c|c|c|c|c|c|c|}
\hline \multirow[t]{2}{*}{ Species } & \multirow[t]{2}{*}{$\mathrm{T}$} & \multirow[t]{2}{*}{$\mathrm{P}(\mu \mathrm{m})$} & \multirow[t]{2}{*}{$E(\mu \mathrm{m})$} & \multicolumn{7}{|c|}{ Shape } & \multirow[t]{2}{*}{ AI } & \multirow[t]{2}{*}{$\mathrm{CL}(\mu \mathrm{m})$} & \multirow[t]{2}{*}{ Exine $(\mu \mathrm{m})$} & \multirow[t]{2}{*}{$\mathrm{SE}$} \\
\hline & & & & $\mathrm{O}$ & So & Os & $\mathrm{S}$ & Ps & $\mathrm{Sp}$ & $\mathrm{P}$ & & & & \\
\hline \multicolumn{15}{|l|}{ Nepeta L. } \\
\hline N. denudata & $\mathrm{C}$ & $23-25.1-26$ & $19-21.9-23$ & - & - & - & - & ++ & + & - & / & $18-20.8-22$ & I & III-e \\
\hline N. eremophila & $\mathrm{C}$ & $27-28.0-28$ & $18-19.9-21$ & - & - & - & - & - & - & ++ & l & $21-23.7-25$ & / & III-d \\
\hline N. floccosa & $\mathrm{C}$ & $19-21.1-23$ & $19-22.1-24$ & - & + & ++ & - & + & - & - & I & $17-18.3-20$ & l & III-e \\
\hline N. glomerulosa & $\mathrm{A}$ & $26-29.0-32$ & $22-25.4-27$ & - & - & \pm & - & ++ & ++ & - & / & $18-21.3-23$ & $0.9-1.0$ & III-e \\
\hline N. glutinosa & $\mathrm{C}$ & $24-28.1-33$ & $30-32.5-37$ & - & + & ++ & - & - & - & - & $0.12-0.22$ & $20-24.9-30$ & / & III-e \\
\hline N. grandiflora & $\mathrm{C}$ & $20-22.7-25$ & $23-24.8-26$ & - & ++ & + & - & \pm & - & - & $0.15-0.20$ & $18-20.0-21$ & / & III-e \\
\hline N. ispahanica & $\mathrm{C}$ & $16-19.9-28$ & $18-21.4-23$ & - & ++ & + & - & - & - & + & $0.13-0.21$ & $14-17.0-25$ & / & III-d \\
\hline N. latifolia & A & $28-30.2-33$ & $23-24.9-28$ & - & - & - & - & \pm & ++ & \pm & l & $19-22.1-26$ & $0.9-1.2$ & III-b \\
\hline N. longibracteata & $\mathrm{C}$ & $30-33.3-38$ & $21-28.6-32$ & - & - & - & - & ++ & + & \pm & / & $25-27.9-32$ & / & III-e \\
\hline N. micrantha & $\mathrm{C}$ & $21-22.6-25$ & $18-21.7-25$ & - & ++ & + & - & ++ & - & - & $0.14-0.20$ & $14-18.0-20$ & / & III-b \\
\hline N. nuda & $\mathrm{C}$ & $19-22.4-24$ & $21-24.2-26$ & - & + & ++ & - & + & - & - & l & $16-19.3-20$ & l & III-e \\
\hline N. olgae & A & $29-32.9-37$ & $22-27.1-30$ & - & - & \pm & - & ++ & + & + & / & $21-25.2-29$ & $0.8-1.0$ & III-e \\
\hline N. pungens & $\mathrm{C}$ & $26-27.8-29$ & $18-21.2-25$ & - & - & - & - & + & + & ++ & l & $18-21.4-24$ & / & III-b \\
\hline N. racemosa & $\mathrm{A}$ & $29-31.9-36$ & $25-28.5-32$ & - & - & \pm & + & ++ & ++ & - & / & $22-24.6-27$ & $0.9-1.1$ & III-e \\
\hline N. racemosa & A & $29-31.0-33$ & $25-28.4-32$ & - & - & \pm & + & ++ & + & - & $0.13-0.22$ & $21-23.6-26$ & $0.9-1.1$ & III-e \\
\hline N. racemosa subsp. crassifolia & $\mathrm{A}$ & $28-30.5-36$ & $26-31.5-36$ & - & \pm & ++ & \pm & + & - & \pm & / & $20-22.9-26$ & $0.9-1.1$ & III-e \\
\hline N. sibirica & A & $43-47.0-51$ & $37.43 .9-51$ & - & \pm & + & - & + & ++ & - & / & $33-37.6-44$ & $0.8-1.1$ & III-b \\
\hline N. teucriifolia & $\mathrm{A}$ & $26-29.2-33$ & $24-29.4-33$ & - & \pm & ++ & - & ++ & \pm & - & / & $18-21.5-25$ & $0.8-1.0$ & III-c \\
\hline N. viscida & A & $32-36.6-40$ & $28-31.0-36$ & - & - & - & - & + & ++ & \pm & $0.12-0.18$ & $25-28.7-33$ & $0.7-1.0$ & III-e \\
\hline \multicolumn{15}{|l|}{ Schizonepeta (Benth.) Briq. } \\
\hline Schizonepeta annua & A & $32-33.9-36$ & $26-28.4-31$ & - & - & - & - & ++ & ++ & - & / & $24-25.1-27$ & $0.9-1.1$ & II \\
\hline Schizonepeta multifida & $\mathrm{C}$ & $18-18.8-19$ & $20-21.2-22$ & - & - & ++ & - & + & - & - & / & $16-16.3-16$ & / & II \\
\hline Schizonepeta tenuifolia & $\mathrm{C}$ & $22-23.6-26$ & $19-21.0-22$ & - & - & - & - & + & ++ & - & / & $18-19.3-21$ & / & II \\
\hline
\end{tabular}

Numbers refer to minimum-mean-maximum except for AI values that correspond to a range. T, treatment method; A, acetolysis; C; critical point dried; P, polar axis; E, equatorial diameter; O, oblate; So, suboblate; Os, oblate spheroidal; S, spherical; Ps, prolate spheroidal; Sp, subprolate; P, prolate; -, absent; \pm , rarely present; +, present; ++, dominant; AI, apocolpium index; /, no data; CL, colpus length; SE, sexine ornamentation type.

classifications of Nepeta should be revised (Jamzad et al., 2003). Dracocephalum is the second largest genus in the Nepetinae, with ca. 70 species classified in three subgenera (Budantsev, 1987, 1993b). Lallemantia was included as a subgenus of Dracocephalum by Budantsev (1993b). However, corolla shape and several molecular studies clearly favor Lallemantia as an independent genus (Bentham, 1848; Wunderlich, 1967; Wagstaff et al., 1995; Jamzad et al., 2003; Harley et al., 2004). For Agastache and Lophanthus, infrageneric delimitations have been suggested by Lint and Epling (1945) and Budantsev (1992a, 1993b). The other eight genera of the Nepetinae each consist of fewer than ten species (including two monotypic genera Drepanocaryum and Cedronella; Budantsev, 1992b); no infrageneric categories have been suggested.

Although Nepetinae is a well defined monophyletic group based on morphological data, morphological synapomorphies for the different genera remain obscure (Harley et al., 2004). A well supported molecular phylogeny of subtribe Nepetinae is still lacking. The present molecular framework of the Lamiaceae has very poor sampling of taxa from the Nepetinae and the relationships between genera are incongruent between analyses (Wagstaff et al., 1995; Jamzad et al., 2003; Walker et al., 2004; Bräuchler et al., 2005; Walker and Sytsma, 2007).

The general pollen morphology within the Nepetinae based on light microscopic (LM) observations, was previously described by Waterman (1960), Varghese and Verma (1968) and Vij and Kashyap (1975). Trudel and Morton (1992) and Wagstaff (1992) used scanning electron microscopy (SEM) to investigate the sexine ornamentation of some selected taxa in the Nepetinae (in total seven species of Agastache, one species each of Dracocephalum, Cedronella and Lophanthus). Jamzad et al. (2000) observed pollen of eleven species belonging to two sections in Nepeta, but this study was restricted to annual species from Iran. Transmission electron microscopic (TEM) observations are not available for the subtribe Nepetinae.

The present study aims to document the pollen morphology and ultrastructure of the pollen wall for a representative sample of the subtribe Nepetinae using LM, SEM and TEM. This study also traces the presence or absence of orbicules since they were never examined in the Nepetinae (Raj and El-Ghazaly, 1987; Huysmans et al., 1998). Furthermore, our palynological observations will be discussed to assess their taxonomic usefulness at inter- and infrageneric level within the Nepetinae and in relation to our previous work on subtribe Salviinae in the tribe Mentheae.

\section{Materials and methods}

The present study is mainly based on herbarium material of 52 representative species (64 specimens) from all genera in subtribe Nepetinae sensu Harley et al. (2004) from the following herbaria: BR, G, GH, K, LV, MO and S (acronyms follow Holmgren et al., 1990), and also in part from plants recently collected by H.-K. Moon (for a complete list of specimens, see Appendix A). The species were selected based on previously recognized infrageneric groups (Bentham, 1848; Briquet, 1897; Budantsev, 1993a,b). 
Drepanocaryum sewerzowi

Lophanthus laxiflorus

Lallemantia roylean

Nepeta cataria

Nepeta glomerulosa

Nepeta assurgen

Nepeta latifolia

Nepeta racemosa
Nepeta teucrifolia

Nepeta teucriffolia

Schizonepeta multifid

Schizonepeta ann

Nepeta racemosa

subsp. crassifolia

Nepeta olgae

Dracocephalum imberbe

Lophanthus tschimganicus

Nepeta viscida

Dracocephalum komarovii

Agastache urticifolia

Agastache scrophulariifolia

Dracocephalum heterophyllum

Dracocephalum nutans

Glechoma hederacea

Agastache urticifolia

Dracocephalum parviflorum

Dracocephalum pinnatum

Dracocephalum ruyschiana

Dracocephalum subcapit
Cedronella canariensis

Lophanthus chinensis

Nepeta sibirica

Agastache palmeri

Dracocephalum fragile

Hymenocrater longiflorus

Dracocephalum grandiflorum

Dracocephalum palmatum

Meehania urticifolia

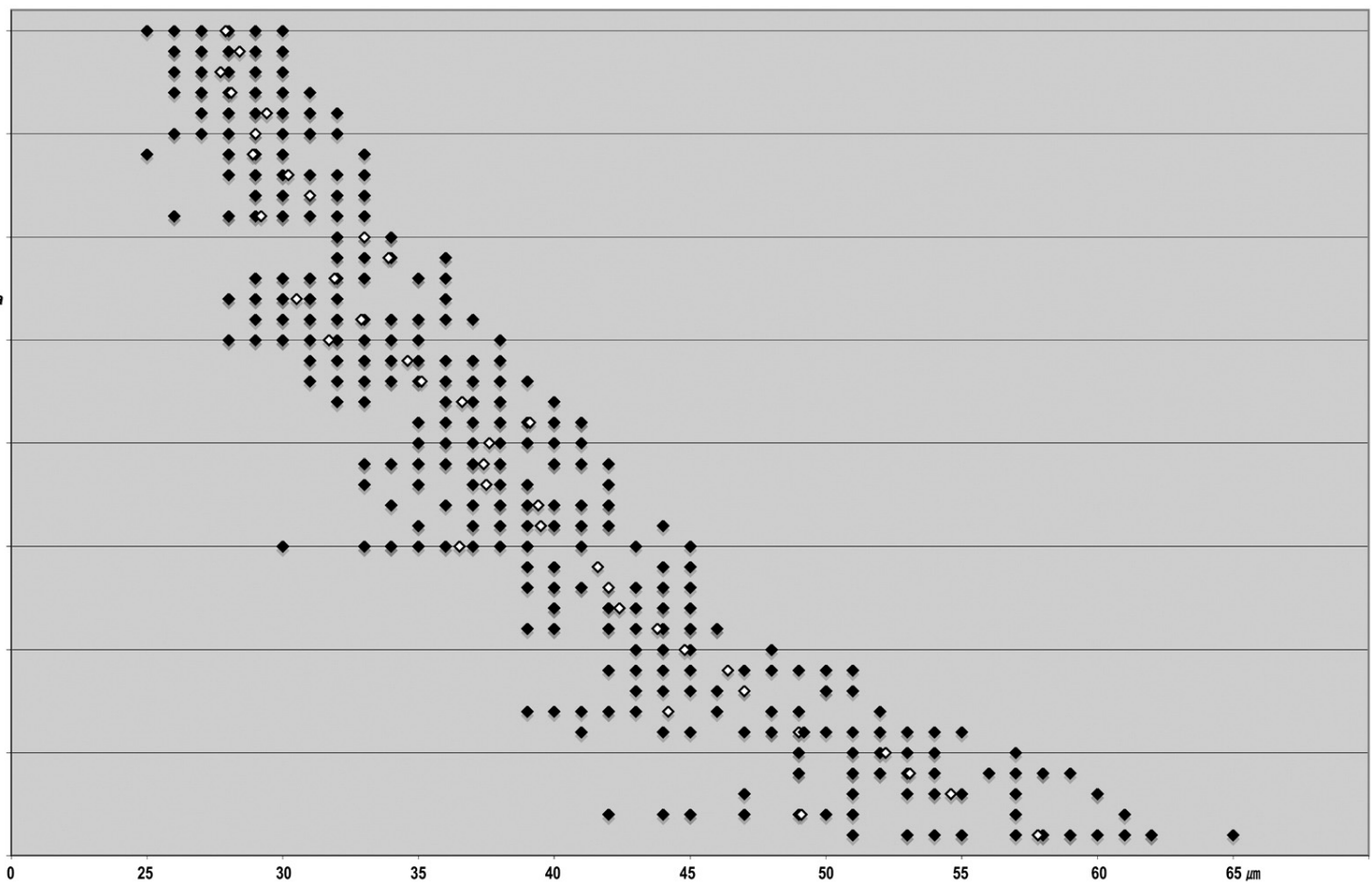

Fig. 1. Pollen size distribution based on polar length of acetolysed pollen grains (see also Table 1) 


\subsection{Pollen and orbicules}

Pollen grains of 38 species were acetolysed according to Reitsma's (1969) method. Pollen descriptions are based on LM and SEM observations. The glycerin jelly slides (LM) were observed using a Leitz Dialux 20 microscope and photographed with an Olympus DP 50 digital camera. In order to fracture some pollen for examination of exine stratification and inner endexine ornamentation, acetolysed grains were placed in an ultrasonic bath for up to $20 \mathrm{~min}$. Acetolysed pollen grains for SEM were suspended in ethanol, air dried on a stub and coated with gold prior to observation with a JEOL JSM-6360 scanning electron microscope at $5-10 \mathrm{kV}$.

Measurements of the length of the polar axis, equatorial diameter, colpus length, and exine thickness were made on 1520 fully developed grains per specimen with LM $(\times 400, \times 1000$ magnification).
For morphological observations of orbicules and pollen, dried flowers or buds from 24 species (including 14 species treated only by critical point drying because the specimens had too few flowers to be acetolysed) were rehydrated for 1-2 h (Agepon wetting agent, 1:200). The anthers were picked from the flowers and the tips removed with a razor blade to facilitate rehydration. After dissection, the anthers remained for one more hour in the wetting agent. Following dehydration in a graded acetone series, the material was critical point dried (CPD 030, Balzers). The dried anthers were mounted on stubs with double adhesive tape. The locules were opened and the pollen grains were carefully removed with a cactus needle. The removed pollen grains were collected on the same stub for SEM observations. Comparative size measurements of acetolysed (AC) and critical point-dried pollen (CPD) were ascertained from SEM photographs using Carnoy 2.0 (Schols et al., 2002). The size correlations using different preparation techniques

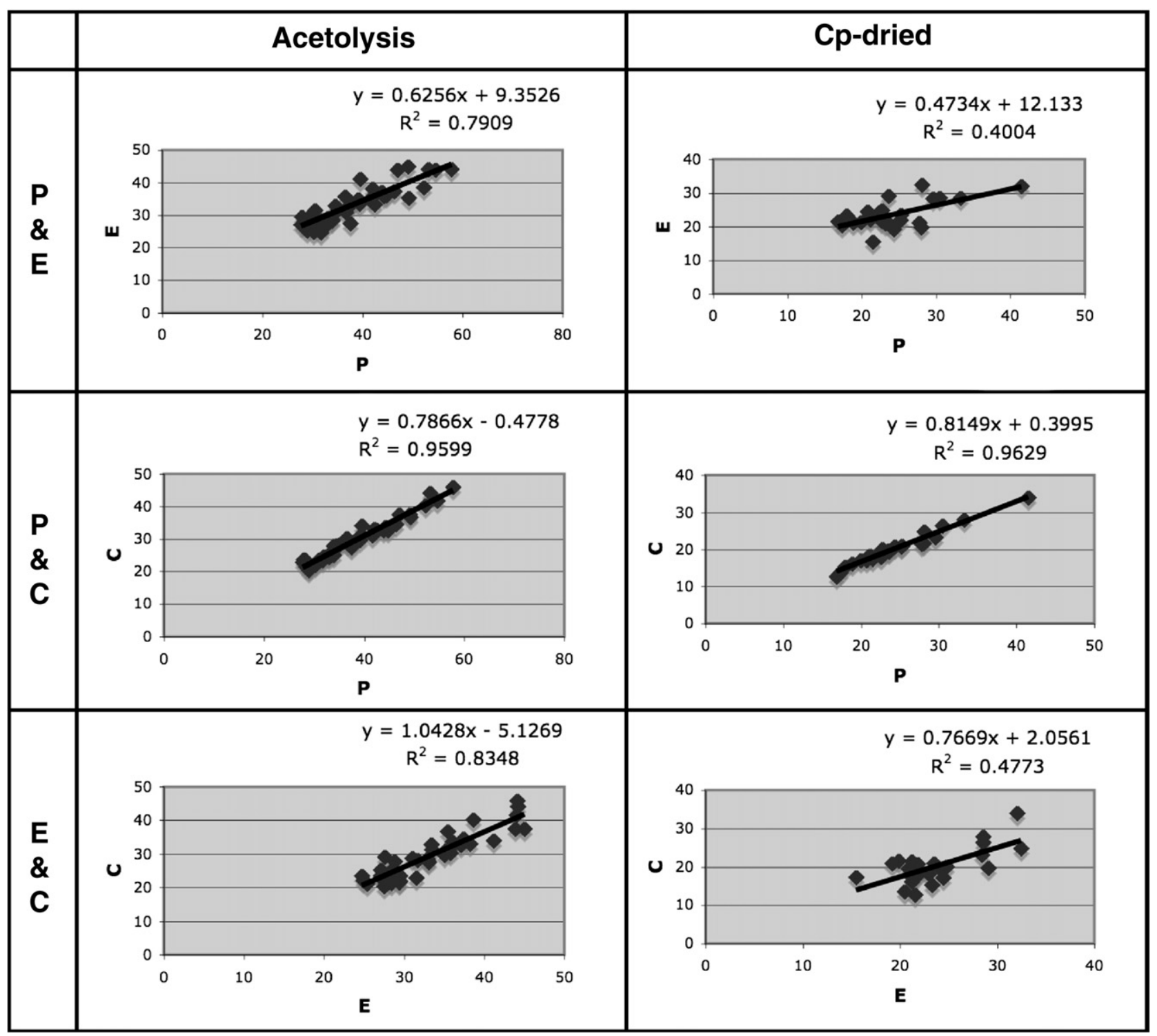

Fig. 2. Results of correlation analyses in order to show influence of different preparation techniques. Each graph includes a trend line and R-squared value as the coefficient of determinations. Each analysis used the mean value of pollen size. $\mathrm{P}=$ Polar length, $\mathrm{E}=\mathrm{Equatorial}$ diameter, $\mathrm{C}=\mathrm{Colpus}$ length. Unit of size $=\mu \mathrm{m}$. 
were calculated using Excel software (Microsoft office 2004 package).

\subsection{Ultrastructure of pollen wall}

For TEM observations, the anthers from living material were directly fixed in $2.5 \%$ glutaraldehyde ( $\mathrm{pH} 7.3$ ) while dried anthers were rehydrated in $0.05 \mathrm{M}$ sodium cacodylate buffer ( $\mathrm{pH} 7.3$ ) prior to fixation. Fixed anthers were rinsed with $0.05 \mathrm{M}$ sodium cacodylate buffer ( $\mathrm{pH} 7.3$ ), followed by post fixation with $2 \%$ $\mathrm{OsO}_{4}$. Prior to embedding in LR-White Resin (Polysciences Inc., Warrington, PA, USA), the material was dehydrated in a graded ethanol series. Semi-thin $( \pm 1 \mu \mathrm{m})$ sections were cut with a Reichert Jung Ultracut E microtome, stained with $0.1 \%$ thionin$0.1 \%$ methylene blue, and observed with a Leitz Dialux 20. The ultra-thin sections were stained with uranyl acetate and lead citrate in an LKB 2168 Ultrastainer, and observed with a Zeiss EM 900 transmission electron microscope at $50 \mathrm{kV}$.

Pollen terminology follows the online edition of the Glossary of Pollen and Spore Terminology (Punt et al., 2007; http:// www.bio.uu.nl/ palaeo/glossary/glos-int.htm).

\section{Results}

Subtribe Nepetinae has small to large $(P=16-65 \mu \mathrm{m}$, $E=17-53 \mu \mathrm{m})$ hexacolpate pollen that is oblate to prolate $(P / E=0.7-1.6)$ in equatorial view and circular in polar view. The pollen wall has a columellar infratectum as in most angiosperms, and orbicules are absent in all taxa studied.

The pollen morphological variation within Nepetinae is described below for the following pollen features: size and shape of pollen grains, number, position and morphology of apertures, sexine ornamentation, and stratification of pollen wall. The representative pollen characters are provided in Table 1 indicating different preparation techniques to discuss possible side effect of the preparation procedure. The pollen size distributions are plotted on the graph in Fig. 1 and the pollen size correlations according to the different preparation techniques are presented graphically in Fig. 2. Representative pollen characters are illustrated in Figs. 3-6.

\subsection{Size}

The pollen grains are dispersed as monads and size varies from small to large (Fig. $1 ; P=16-65 \mu \mathrm{m}, E=17-53 \mu \mathrm{m}$ ) with striking size differences according to the preparation methods. The size of critical point dried pollen grains is always smaller in comparison with acetolysed grains, ca. $12-47 \%$ (both observed with SEM; see also Appendix A). In both preparation techniques, however, the smallest grain is present in Drepanocaryum sewerzowii (AC: $P=25-30 \mu \mathrm{m}, \mathrm{CPD}$ : $P=16-$ $17 \mu \mathrm{m}$ ) while Meehania urticifolia (AC: $P=51-65 \mu \mathrm{m}, \mathrm{CPD}$ : $P=35-51 \mu \mathrm{m}$ ) has the largest pollen grain (Fig. 3A). Within the same genus, such as Agastache, Lallemantia and Schizonepeta, taxa show similar size variation although the genus Lophanthus shows remarkable size differences among its taxa (Table 1; Fig. 1). Nepeta sibirica and N. longibracteata have large pollen grains in comparison with other members of $\mathrm{Ne}$ peta (Table 1; Fig. 1).

\subsection{Shape}

The shape of the pollen grains in equatorial view ranges from oblate to prolate $(P / E=0.7-1.6)$, but most taxa studied are oblate-spheroidal to subprolate (Fig. 3G-I; Table 1). The polar length is strongly correlated with the equatorial diameter in acetolysed pollen $\left(R^{2}=0.79\right)$ while there is no significant relation in critical point dried pollen (Fig. 2; $R^{2}=0.40$ ). However, shape classes can vary considerably within the same species excluding the effect of preparation techniques (Table 1). The shape in polar view is more or less circular in all taxa studied (Fig. 3B-C, D-F).

\subsection{Apertures}

Pollen of the Nepetinae is predominantly hexacolpate (Fig. 3AB, D-E), sometimes mixed with some octocolpate grains (less than 1\%; e.g., Glechoma hederacea, Hymenocrater bituminosus, H. longiflorus and Meehania urticifolia; Fig. 3C, F).

Simple colpi are distributed symmetrically (Fig. 3B-F). The colpus length ranges between $11-55 \mu \mathrm{m}$ and is strongly correlated with polar length (Fig. $2 ; R^{2}=0.96$ ). The apocolpium index (AI) is the ratio of the distance between the apices of two ectocolpi to its equatorial diameter. The value is an indirect measure of the length of the ectocolpi. In the Nepetinae, the apocolpium index varies between 0.11 and 0.31 (Table 1). Colpi are narrow towards the poles and have coarsely granular membranes (only visible on CPD material - Fig. 3G-L).

\subsection{Sexine ornamentation}

The sexine ornamentation in the Nepetinae is microreticulate, perforate or bireticulate, and the exine thickness varies between 0.7-2.1 $\mu \mathrm{m}$ (Table 1; Figs. 4 and 5).

The microreticulate pattern can be divided into two types according to the secondary tectal connections visible at the lower plane. The simple microreticulate pattern is found in Dracocephalum fragile, D. grandiflorum, D. heterophyllum, D. imberbe D. komarovii, D. pinnatum and Glechoma hederacea (Type I-a; Fig. 4A), while Dracocephalum parviflorum, D. ruyschiana, D. scrobiculatum, D. subcapitatum and Lallemantia peltata possess microreticulate pattern with secondary tectal connections of irregular round lumina (Type I-b; Fig. 4B). The genus Hymenocrater (H. bituminosus, $H$. longiflorus) has a microreticulate sexine pattern with polygonal lumina and a secondary reticulum at a slightly lower plane (Type I-c; Fig. 4C).

Perforate ornamentation with secondary tectal connections is found in Schizonepeta (S. annua, S. multifida, S. tenuifolia Type II; Fig. 4D).

Bireticulate sexine ornamentation can be divided into several subtypes based on thickness of primary muri, shape of primary lumen and shape and number of secondary lumina. Dracocephalum stamineum has wide primary muri with a very shallow secondary reticulum in the primary lumen (Type III-a; Fig. 4E). 

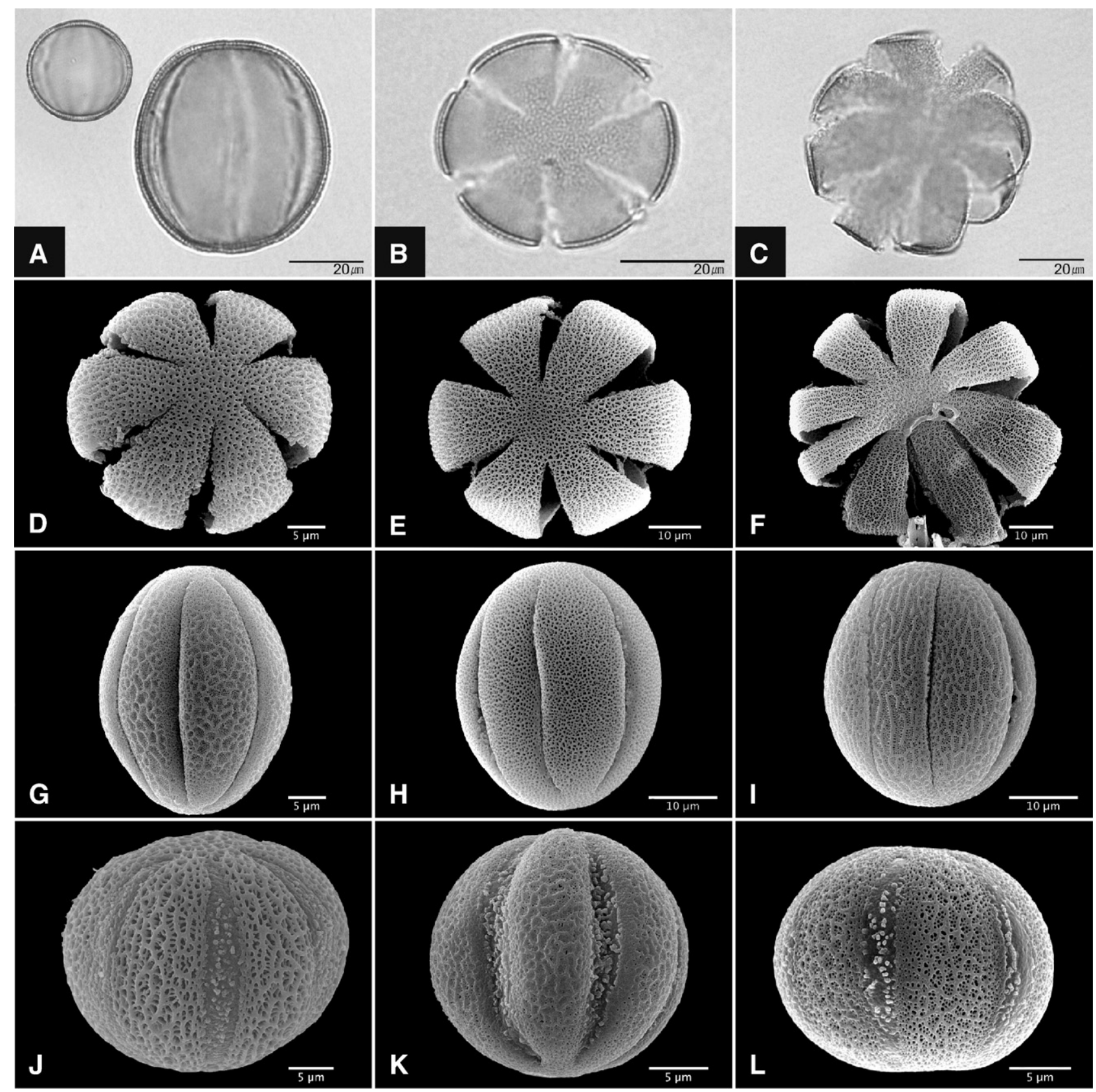

Fig. 3. LM and SEM micrographs of pollen grains of Nepetinae. A. Size variation - left; Drepanocaryum sewerzowii (smallest pollen), right; Meehania urticifolia (largest pollen). B. Polar view of Glechoma hederacea. C. Octocolpate pollen grain of Meehania urticifolia, D. Polar view of Lophanthus tschimganicus. E-F. Polar view of Hymenocrater longiflorus — E; Hexacolpate pollen, F: Octocolpate pollen. G-I. Equatorial view of pollen grains from acetolyzed material. G. Agastache urticifolia. H. Glechoma hederacea. I. Lophanthus chinensis. J-K. Equatorial view of pollen grains from critical point-dred material (CPD). J. Hymenocrater bituminosus. K. Nepeta cephalotes. L. Nepeta olgae. - All micrographs in figures based on acetolysed pollen grain when mentioned otherwise.

The primary muri are thicker than the secondary muri with some discontinuous angular shape; the number of secondary lumina is over ten per primary lumen in Drepanocaryum sewerzowii, Lophanthus tschimganicus, Nepeta latifolia, N. micrantha, $N$. pungen and N. sibirica (Type III-b; Fig. 4F). The primary muri are elongated in shape in Lophanthus chinensis and $N$. teucriifolia with distinctly secondary reticulum (Type III-c; Fig. 4G). The primary muri are irregular in pattern and sometimes discontinuous; the secondary reticulum consists of more than 20 rounded lumina in Cedronella canariensis, D. nutans and
D. palmatum $N$. eremophila, N. ispahanica (Type III-d; Fig. 4H-I). Agastache scrophulariifolia has heteromorphic sexine ornamentation with thick primary muri. On the alternate position three mesocolpia have a primary lumen with a few secondary reticulum. Three other mesocolpia and the apocolpium area have large and discontinuous primary muri with more than 10 secondary lumina (Fig. 4J). All other taxa studied possess a bireticulate sexine ornamentation, which characterized by the primary lumen of closed angular shape with well differentiated secondary reticulum (Type III-e; Table 1; Fig. 4K-L). 

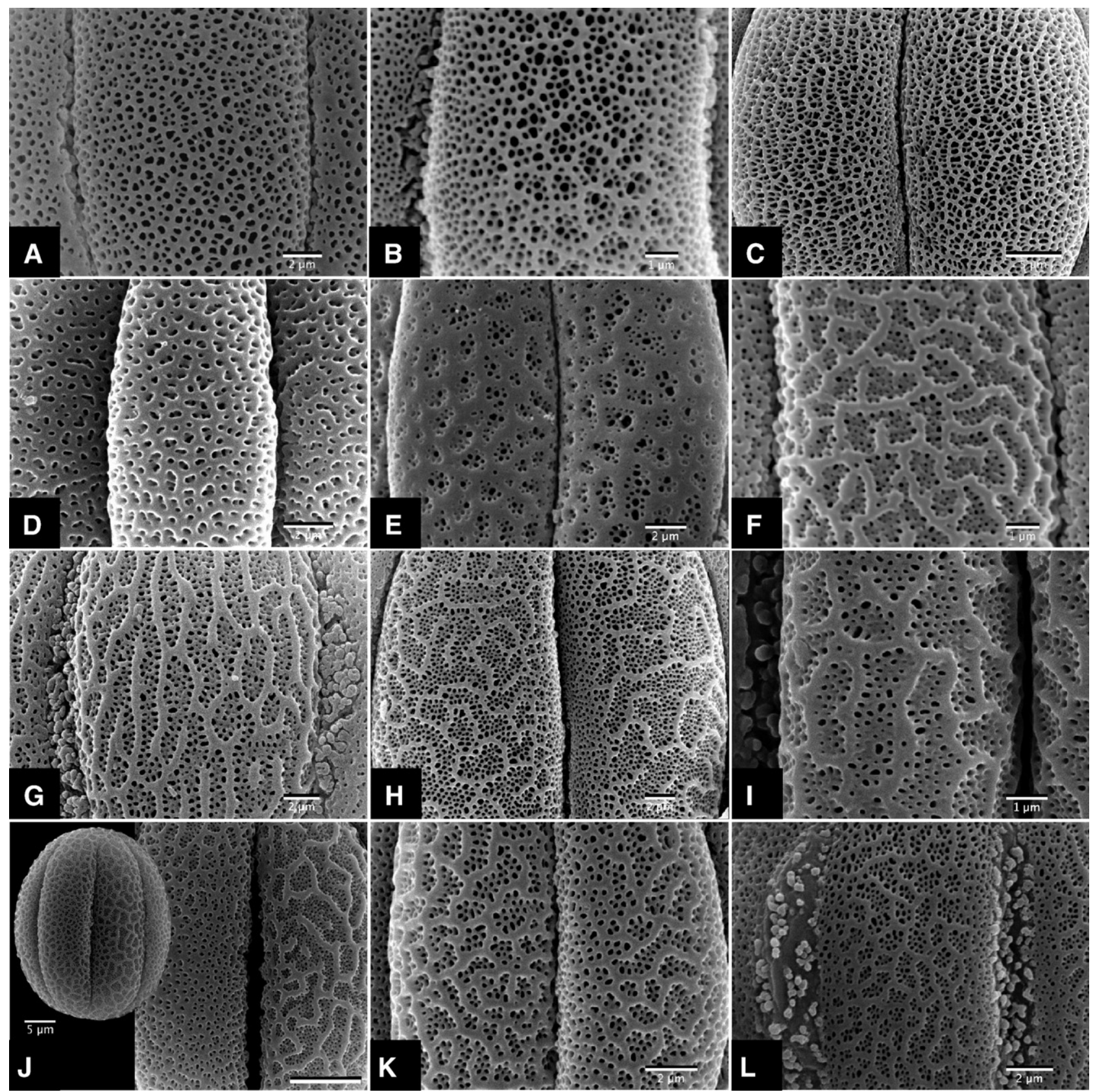

Fig. 4. SEM micrographs of sexine ornamentation in Nepetinae. A. Reticulate sexine ornamentation of Glechoma hederacea, B. Reticulate sexine ornamentation with possible secondary tectal connections visible in Lallemantia peltata, C. Reticulate sexine ornamentation with secondary reticulum in Hymenocrater longiflorus, D. Perforate sexine ornamentation with subsidiary tectal connections of the lumen in Schizonepeta multifida, E-L. Variations of bireticulate sexine ornamentation. E. Dracocephalum stemineum, F. Lophanthus chinensis, G. Drepanocaryum sewerzowii, H. Cedronella canariensis, I. Nepeta eremophila (CPD), J. Agastache scrophulariifolia, K. Nepeta racemosa, L. Nepeta floccosa (CPD).

\subsection{Pollen wall stratification and ultrastructure}

All taxa studied show the same exine stratification (Fig. 5). The tectum is thicker than the foot layer. Columellae are simple, unbranched and densely spaced. The foot layer is continuous (Fig. 5C-E) or distinctly discontinuous (Fig. 5D). It is relatively thin and supported by a very thin, often hardly visible endexine (Fig. 5E). Under SEM, the inner endexine of acetolysed broken grains has a granular ornamentation (Fig. 5A-B). The intine is thicker below the colpi than at the mesocolpia. Two strata can clearly be distinguished: an electron dense inner layer that is continuous, and a more electron lucent layer of similar thickness restricted to the apertural regions (Fig. 5C). Pollenkitt is accumulated in the infratectum (Fig. 5C-D).

\subsection{Orbicules}

All taxa studied have a unique type of anther with two thecae (Fig. 6A). The outer wall of the anther has angular cells with a cuticle layer (Fig. 6B) and the filament is covered cuticle with 
linear cells (Fig. 6C). The inner locule walls display a characteristic pattern revealing the underlying star-shaped thickenings of the endothecium cells. The tapetal membrane is completely smooth without any sporopollenin deposits. Orbicules were absent in all taxa studied (Fig. 6D-E).

\section{Discussion}

\subsection{Impact of preparation technique on size and shape}

All previous pollen studies in the Nepetinae are based on acetolysed material, and the size range of the acetolysed pollen grains in the present study is similar. However, the size of pollen is strikingly affected by different preparation treatments (Reitsma, 1969; Harley, 1992; Schols et al., 2004; Lens et al., 2005; Moon et al., in press). Our results show that critical point-dried (CPD) pollen grains are always smaller (12-47\%) than the acetolysed grains. The size of critical point-dried pollen grains probably resembles more the natural size, since pollen taken directly from herbarium material without pretreatment has a similar size range compared to critical pointdried pollen grains (H.-K. Moon, pers. obs.).

The preparation technique applied also affects pollen shape. The standard acetolysis method destroys the colpus membranes and modifies the natural shape of the pollen grain (Demissew and Harley, 1992). This leads to pollen grains sometimes being erroneously described as "prolate" in the literature while their natural shape is more likely to range from oblate spheroidal to subprolate (Harley et al., 2004). Size correlations between polar length and equatorial diameter reflect a general effect of the preparation techniques. Acetolysed pollen has a significant size correlation in contrast to the CPD pollen (Fig. 2). The taxa studied tend to possess a suboblate shape after CPD while acetolysed pollen grains have a subprolate shape. However, a prolate shape is naturally dominant in the CPD pollen grains of Glechoma hederacea, Lophanthus laxiflorus, L. tschinganicus and N. cataria (Table 1).

Obviously, critical point drying preserved the natural shape and size of pollen with intact apertural membranes, whereas the pollen wall structure and inner nexine ornamentation could only be observed on acetolysed pollen grains.

\subsection{General pollen characters for the Nepetinae}

Aperture number has been considered as a useful character to define the subfamily Nepetoideae. This subfamily is characterized by hexacolpate pollen grains with three nuclei at maturity/ dispersal (Erdtman, 1945; Cantino, 1992). All taxa examined in the present study are hexacolpate, although a few octocolpate pollen grains were also produced in Glechoma hederacea, Hymenocrater bituminosus, H. longiflorus, Meehania urticifolia and N. viscida (Fig. 3C, I). Many species produce simultaneously pollen with different aperture numbers: this
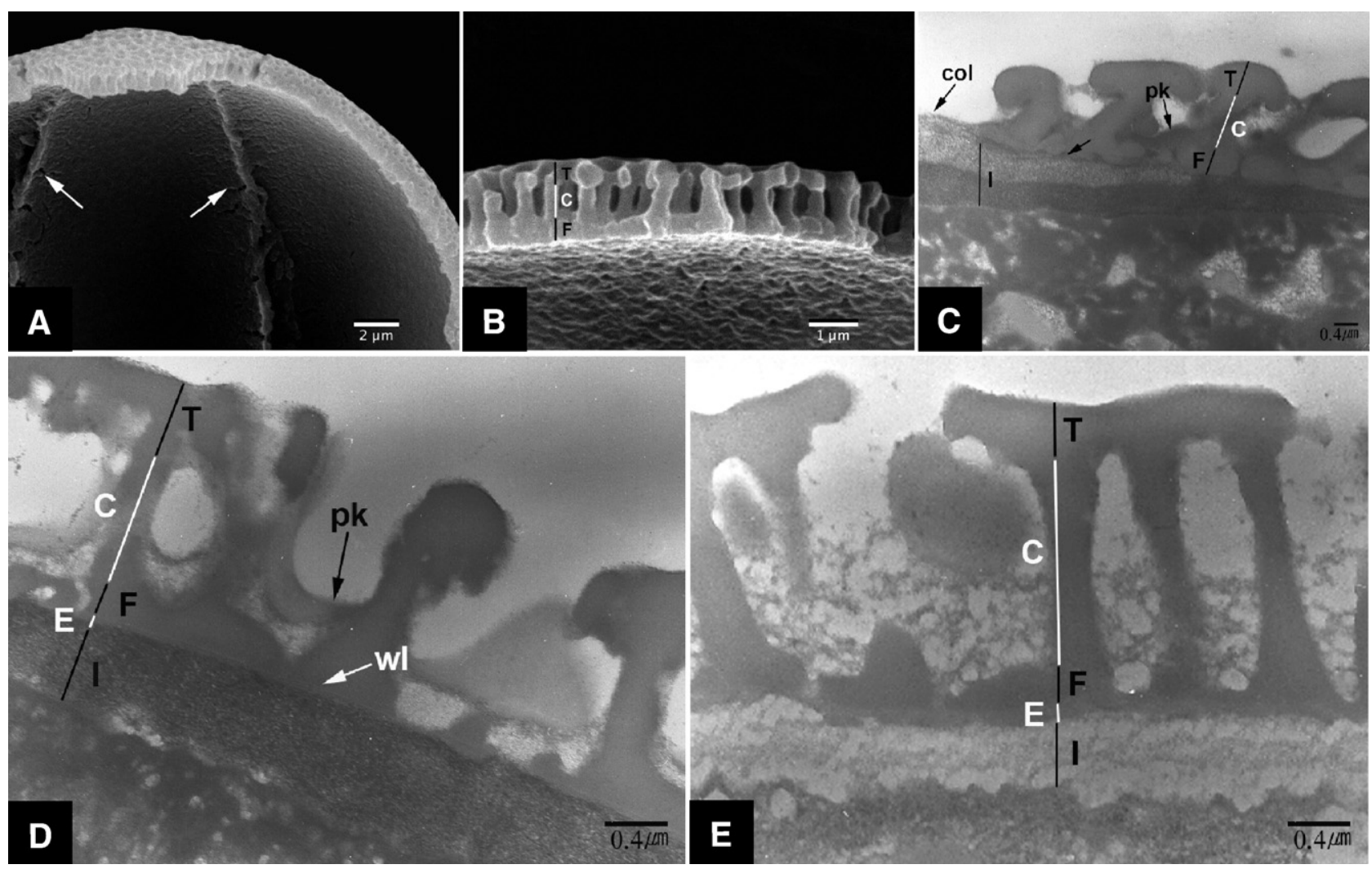

Fig. 5. SEM and TEM micrographs of pollen wall of Nepetinae. A-B. Exine stratification and undifferentiated endexine ornamentation with a densely granular texture; white arrows indicate the aperture slit. A. Glechoma hederacea. B. Hymenocrater longiflorus. C-E. TEM observations of the ultrastructure of the pollen wall. C. Cedronella canariensis. D. Magnified part of the wall to emphasize the endexine with remains of the 'white line' (white arrow) and deposit of pollenkitt (black arrows) in the infratectum — Dracocephalum komarovii. E. Glechoma hederacea. — colpus (col), tectum (T), columellae (C), foot layer (F), endexine (E), intine (I), pollenkitt (pol), white line (wl). 


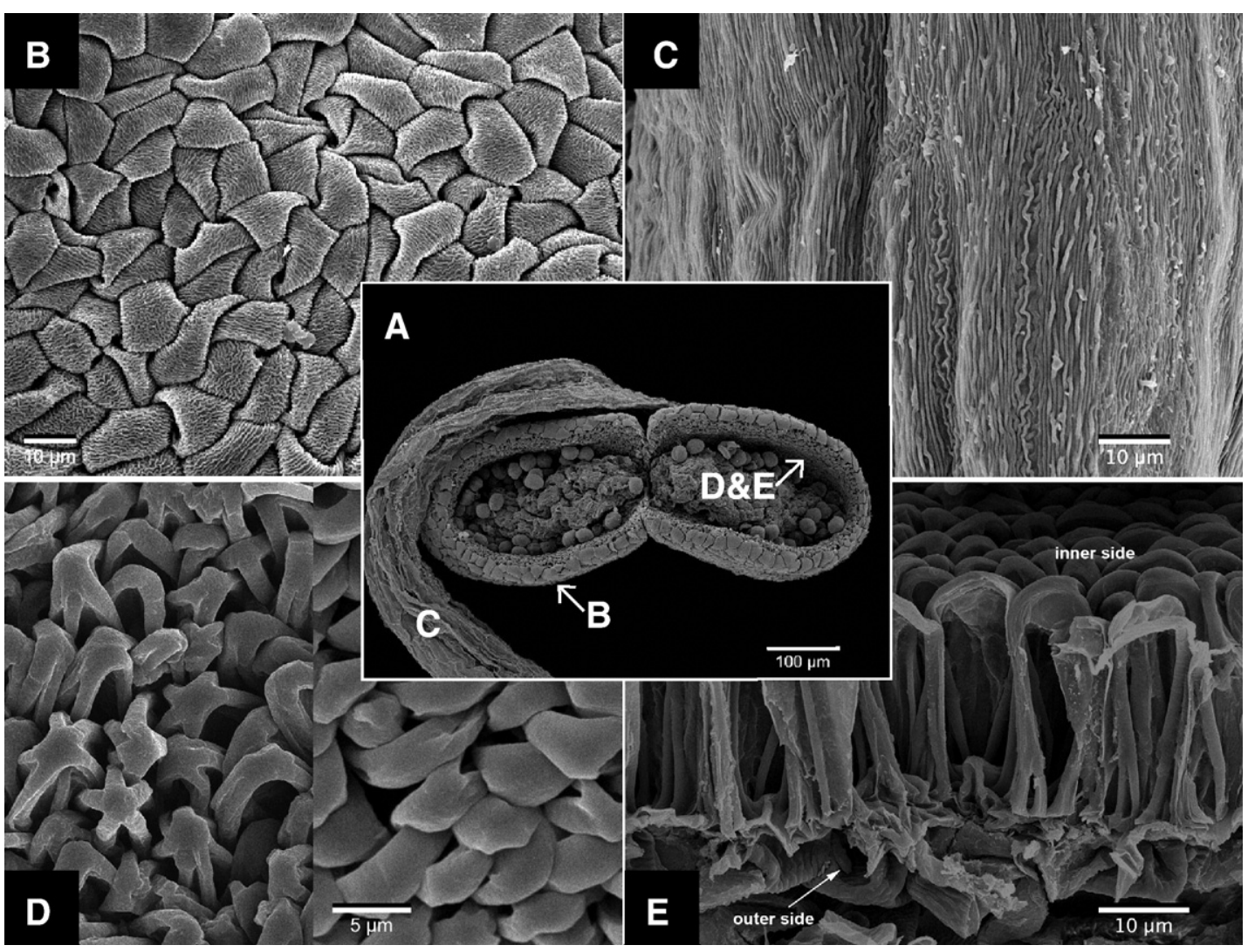

Fig. 6. SEM micrographs of anther of Nepetinae. A. Anther with two thecae of Nepeta cataria. B. Detail of cell structure of outer side of anther - Nepeta grandiflora. C. Detail of cell structure of filament — Lophanthus laxiflorus, D. Inner locule wall with no traces of orbicules — left; Glechoma hederacea, right; Lallemantia peltata. E. Structure of the endothecium thickenings in cross section of Nepeta eremophylla. — all micrographs based on critical point-dried material.

has been referred to as pollen aperture heteromorphism (Mignot et al., 1994; Till-Bottraud et al., 1994, 1995). It occurs quite often throughout the other genera of Lamiaceae (Trudel and Morton, 1992; Abu-Asab and Cantino, 1993, 1994; Moon et al., in press). This syndrome has been considered closely related with pollen germination and polyploidy conditions (Bronckers, 1963; Erdtman, 1966), although some case studies (Kessler and Larson, 1969; Cartier, 1971; Dajoz, 1990) provide evidence that there is no clear relation between aperture numbers and polyploidy eliminate.

Pollen wall stratification is a stable character in the Nepetinae. All taxa studied have basically the same exine stratification consisting of simple columella and a continuous thin granular endexine (Fig. 5). Such exine stratification also occurs in subtribe Salviinae and is common in subfamily Nepetoideae (Nabli, 1976; Harley, 1992; Harley et al., 1992; Moon and Hong, 2003; Moon et al., in press).

\subsection{Systematic implications of sexine ornamentation}

The observed variation of sexine ornamentation proved to be a useful taxonomic character in the Nepetinae. Sexine ornamentation is microreticulate, perforate or bireticulate. The most common sexine ornamentation is bireticulate, which consists of angular primary lumina with a fine secondary reticulum (Fig. 4K-L). This type of sexine ornamentation evolved in several genera of Nepetinae as well as other Lamiaceae (Abu-
Asab and Cantino, 1992, 1994; Wagstaff, 1992; Trudel and Morton, 1992; Jamzad et al., 2000; Moon et al., in press).

Glechoma hederacea, Lallemantia peltata and some species of Dracocephalum have a microreticulate sexine, which tends towards a bireticulum with differentiated traces of a secondary reticulum (Fig. 4A-B). Genus Glechoma possess the same sexine ornamentation with Dracocephalum, while genera Agastache, Drepanocaryum, Lophanthus, Marmoritis and Meehania have the similar sexine ornamentation as Nepeta. Historically, Lallemantia was considered closely related to Dracocephalum (Briquet, 1897; Budantsev, 1993b). It is also interesting to note that Dracocephalum and Lallemnatia show variation of sexine ornamentation while all other taxa studied produce basically the same sexine ornamentation type at the generic level (Table 1). Lallemantia peltata possesses the same sexine ornamentation as Dracocephalum, however, all other characters are different (Table 1). In addition, Lallemantia royleana shares the same sexine ornamentation with Nepeta. Lophanthus is closely allied to Nepeta (Budantsev and Lobova, 1997). The section Psilonepeta of Nepeta has been transferred to Lophanthus by Levin (1941) and Budantsev (1992a). According to Jamzad et al. (2003), section Psilonepeta emerged from Nepeta forming a separate subclade. Lophanthus laxiflorus (sect. Psilonepeta) has bireticulate sexine type III-e and Lophanthus chinensis has an elongated lumina shape (type III-c) like that of Nepeta teucriifolia (sect. Schizocalyx; Fig. 4G). Our palynological results that Lophanthus might belong to Nepeta sensu lato. 
For the infrageneric relationships within Nepeta and Dracocephalum it is noteworthy that the microreticulate patterns (type I) are restricted to Dracocephalum while bireticulate ornamentation with angular and thick primary muri (type III-e) occurs only in Nepeta (Table 1). However the variation of sexine ornamentation partly corresponds with previous infrageneric hypotheses (Bentham, 1848; Briquet, 1897; Pojarkova, 1954; Budantsev, 1993a; Budantsev and Lobova, 1997). For example, Dracocephalum stamineum belongs to the subgenus Fedtschenkiella and has a distinct type of sexine ornamentation (type III-a; Fig. 4E). All taxa studied from sects. Nepeta, Spicata and Denudatae of Nepeta have bireticulate sexine ornamentation type III-e, whereas same sexine ornamentation type often occurs in the different sections (Table 1). The infrageneric classification by Jamzad et al. (2003) based on ITS sequence data was also not supported either by pollen morphology. However, our sampling for Nepeta is insufficient to address the infrageneric relationships based on pollen data alone. Nevertheless, our palynological data show that a combined approach, using morphological and molecular data, is recommended to reconsider the classification within the genus Nepeta.

\subsection{Orbicules}

Orbicules are small sporopollenin particles, which can be produced on the radial and inner tangential walls of tapetal cells (Huysmans et al., 1998, 2000). Orbicules are consistently absent in all taxa investigated (Fig. 6D-E). The presence of orbicules is generally considered to be a plesiomorphic trait since they are restricted to species with a secretory tapetum, which occurs predominantly in basal angiosperms (i.e.,Furness and Rudall, 1998). From the study on Lavandula dentata it is clear that this species has a secretory tapetum without orbicules (SuarezCervera and Seoane-Camba, 1986). Unfortunately, no literature data are available about tapetum characteristics for the Nepetinae.

In Lamiaceae, orbicules have been observed to date only in the tribe Chloantheae (Raj and El-Ghazaly, 1987). It is interesting to note that tribe Chloantheae has a basal position in Lamiaceae, while the subtribe Nepetinae is a more derived group without orbicules. In addition, subtribe Salviinae of Mentheae also has smooth locule walls without any orbiculelike sporopollenin deposition (Moon et al., in press).

\section{Conclusion}

Hexacolpate pollen grains, pollen wall stratification consisting of unbranched columellae, and a continuous, granular endexine are probably symplesiomorphic characters for subtribe Nepetinae. Orbicules are consistently absent in both Nepetinae same as Salviinae. The sexine ornamentation in Nepetinae is variable and could be systematic significance, however the current infrageneric classification of genera Dracocephalum and Nepeta is only partly congruent with the present pollen morphological data. The observed variation in sexine ornamentation is particularly valuable at the generic level. Therefore, we plan a palynological study of subtribe Menthinae to complete the pollen survey of the entire tribe Mentheae in order to provide an overview of its pollen diversity.

\section{Acknowledgements}

We thank the directors of the herbaria of BR, G, GH, K, LV, $\mathrm{MO}$ and $\mathrm{S}$ for permitting the examination of specimens, either through loans or during visits. Sincere thanks are also due to two anonymous reviewers for their critical reading of manuscript and helpful suggestions. We are also grateful to Anja Vandeperre (K.U.Leuven) and An Vandoren (TEM, K.U. Leuven) for technical assistance. H.-K. Moon thanks Dr. Ian Hedge (Royal Botanic Garden Edinburgh) and Dr. Alan Paton (Royal Botanic Gardens, Kew) for their continuous help and encouragement. A personal research grant of the K.U.Leuven (DB/06/054) was awarded to H.-K. Moon. The Fund for Scientific Research-Flanders (FWO, G.0268.04 and G.0250.05)

\section{Appendix A. Voucher specimens of the subtribe Nepetinae which are examined in the present study}

\begin{tabular}{|c|c|c|c|}
\hline Species & Section & Voucher information & \\
\hline Agastache palmeri (B.L.Rob.) Standl. & Sect. Brittonastrum & Mexico, 20. 11. 1975. Peterson \& Broome 485 BR & \\
\hline A. scrophulariifolia (Willd.) Kuntze & Sect. Agastache & U.S.A., 25.7.1968. Leonard \& Moore 1829 BR & \\
\hline A. urticifolia (Benth.) Kuntze & Sect. Agastache & $\begin{array}{l}\text { U.S.A., 26.6.1996. Bouharmont } 26820 \text { BR } \\
\text { U.S.A. 7. 1886. Howell s.n., BR } \\
\text { U.S.A., 28.6.4. Evrard } 12840 \text { BR }\end{array}$ & $\mathrm{O}$ \\
\hline Cedroneall canariensis (L.) Webb \& Berthel & & Canary Is., 23.6.1855. Perraudiere s.n. GH & $\mathrm{T}$ \\
\hline Dracocephalum fragile Turcz. ex Benth. & Dracocephalum/ Palmata ${ }^{1}$ & $\begin{array}{l}\text { Canary Is., 11.7.1823. Perrottet s.n. GH } \\
\text { without locality and date, Fischer } 1836 \text { BR }\end{array}$ & $\mathrm{O}$ \\
\hline D. grandiflorum $\mathrm{L}$. & Dracocephalum/Calodracon $^{1}$ & Russia, Andrejew s.n. BR & \\
\hline D. heterophyllum Benth. & Dracocephalum/Dracocephalum $^{1}$ & Kyrgyzstan, 12.8.1926. Sovetkina s.n. BR & \\
\hline D. imberbe Bunge & Dracocephalum/Calodracon $^{1}$ & Uzbekistan, 22-23.7.1923. Mokeeva \& Popov s.n. BR & \\
\hline D. komarovii Lipsky & Dracocephalum/Dracocephalum $^{1}$ & Kyrgyzstan, 19.7.1927. Sovetkina s.n. BR & $\mathrm{T}$ \\
\hline D. nutans L. & Dracocephalum/Idiodracon $^{1}$ & Russia, 12.5.1869. Bullemont s.n. BR & \\
\hline D. palmatum Steph. ex Willd. & Dracocephalum/Palmata ${ }^{1}$ & Russia, 24.7.1974. Kharkevich 673a BR & $\mathrm{T}$ \\
\hline D. parviflorum Nutt. & Dracocephalum/Cryptodracon ${ }^{1}$ & Canada, 22.6.1978. Collet $111 \mathrm{BR}$ & \\
\hline D. pinnatum $\mathrm{L}$. & Dracocephalum/Keimodracon $^{1}$ & Russia, without date, Karelin \& Kiriloff 1841 BR & \\
\hline D. ruyschiana $\mathrm{L}$. & Subgenus Ruyschiana & Russia, 28.7.1981. Vašák s.n. BR & $\mathrm{O}$ \\
\hline D. scrobiculatum Regel & Dracocephalum/Confertodracon ${ }^{1}$ & Russia, 12.7.1962. Bacuraeba s.n. BR & \\
\hline D. stamineum Kar. \& Kir. & Subg. Fedtschenkiella & Tajikistan, 5.9.1935. Rajokova 6774 BR & \\
\hline
\end{tabular}


Appendix A (continued)

\begin{tabular}{l} 
Species \\
\hline D. subcapitatum (Kuntze) Lipsky \\
Drepanocaryum sewerzowii (Regel) Pojark. \\
Glechoma hederacea L. \\
Hymenocrater bituminosus Fisch.\& C.A.Mey. \\
H. longiflorus Benth. \\
Lallemantia peltata (L.) Fisch. \& C.A.Mey
\end{tabular}

Lallemantia royleana (Benth.) Benth.

Lophanthus chinensis Benth. Lophanthus laxiflorus (Benth.) Levin Lophanthus tschimganicus Lipsky Marmoritis rotundifolia Benth.

Meehania urticifolia (Miq.) Makino

Nepeta assurgens Hausskn. \& Bornm. ex Bornm. N. cataria L.

N. cephalote Boiss.

$N$. denudata Benth.

N. eremophila Hausskn. \& Bornm. ex Bornm.

N. floccosa Benth.

N. glomerulosa Boiss.

N. glutinosa Benth.

N. grandiflora M.Bieb.

N. ispahanica Boiss.

N. latifolia DC.

N. longibracteata Benth.

$N$. micrantha Bunge

N. nuda L.

N. olgae Regel

$N$. pungens (Bunge) Benth.

N. racemosa Lam.

N. racemosa subsp. crassifolia (Boiss. \& Buhse) A.L.Butantsev.

$N$. sibirica $\mathrm{L}$.

N. teucriifolia Willd.

$N$. viscida Boiss.

Schizonepeta annua (Pall.) Schischk.

Schizonepeta multifida (L.) Briq.

Schizonepeta tenuifolia (Benth.) Briq.
Sect. Lophanthus Sect. Psilonepeta Sect. Lophanthus

Sect. Spicata

Sect. Nepeta

Sect. Denudatae

Sect. Denudatae

Sect. Micranthae

Sect. Capituliferae

Sect. Sparthonepeta

Sect. Brachystegiae

Sect. Nepeta

Sect. Micranthae

Sect. Orthonepeta

Sect. Glechomanthe

Sect. Micranthae

Sect. Orthonepeta

Sect. Capituliferae

Sect. Micronepeta

Sect. Nepeta

Sect. Nepeta

Sect. Macronepeta

Sect. Schizocalyx

Sect. Subinterruptae Voucher information

Turkmenistan, 5.7.1923. Korovin 209 BR

Tajikistan, 23.5.1974. Vašák \& Ziatník s.n. BR O

Denmark, 2.6.1972. Larsen et al. 194 BR

Belgium, 1977. Witte 15820, BR

Belgium, 7.5.2006. Moon 001 LV

Iran, 28.6.1942. Kyilbynacob s.n. BR

Turkey, 1864. Haussknecht s.n., BR

Russia7.5.1982. Vašák s.n., BR

Without locality, 6.2002. Dagh s.n., BR

Iran, 27.4.1892. Bornmüller 4269 BR

Iran, 4.5.1972. Léonard 5385 BR

China, 27.6.1867. Bullemont s.n. BR

Iran, 3.7.1971. Rechinger $42798 \mathrm{~S}$

Uzbekistania, 9.8.1926. Baranov \& Raikova s.n. BR

China, 20.7.1979. Hartmann 2464 G

Japan, 26.4.1899. Makino s.n. BR

Japan, 8.1936. Makino s.n. BR

Japan, 18.6.1973. Kanai \& Ohashi 731216 BR

Iran, 18.7.1892. Bornmüller 5126 BR

France, 18.7.1993. Rastetter 16394 BR

France, 18.7.1975. Kapp s.n. LV

Iran, 4.9.1948. Manoutcheri \& Aellen s.n. BR

Iran, 24.8.1948. Aellen. s.n. BR

Iran, 2.5.1892.Anonymus s.n. BR

India, 4.7.1976. Billiet \& Leonard 6813. BR

Iran, 8.7.1948. Aellen 830 BR

India, 7.7.1976. Billiet \& Leonard 6822 BR

Spain, 10.7.1917.Sennen s.n. LV

Italian Republic, 15.7.1878. Figo s.n. BR

Iran, 22.8.1976. Lambinon 76/314 BR

France, 6.8.1876 Garroute 1341 BR

China, without date, Coll J.J. BR

Iran, 29.2.1892. Bornmüller 5119. BR

Without locality, 6.7.1973. Lawalree 18115 LV

Uzbekistan, 22.5.1924. Popov \& Vvedensky 205 BR

Central Asia, 8.6.1934. Parsa s.n. BR

Turkey, 3.8.1894. Haussknecht 7021 BR

Russia, 5.5.1985. Vašák s.n BR

Iran, 23.7.1948. Behboudi and Aellen s.n. BR

Russia, without date, Lindemann.s.n. BR

Armenia, 4.7.1894. Sintenis 6096 BR

Turkey, 6.1996. Victoor s.n. BR

Central Asia, without date, Lead s.n. MO

Russia, 20.7.1974. Ame $\pi$ byehko \& CbnpnIIehko s.n. MO O

Japan, Tsumura, pref. Tokyo 1932. Makino s.n. BR

$-{ }^{1}$ Subgenus/sect; O, Orbicule presence checked; T, TEM observation.

-Infrageneric delimitations of genera by Lint and Epling (1945, Agastache), Sanders (1987, Agastache), Budantsev (1993a, Nepeta; 1993b Dracocephalum, Agastache and Lophanthus).

and the K.U.Leuven $(\mathrm{OT} / 05 / 35)$ financially supported this research. S. Vinckier was a postdoctoral fellow of the Fund for Scientific Research-Flanders (FWO) in the course of this study.

\section{References}

Abu-Asab, M.S., Cantino, P.D., 1992. Pollen morphology in subfamily Lamioideae (Labiatae) and its phylogenetic implications. In: Harley, R.M., Reynolds, T. (Eds.), Advances in Labiatae Science. Royal Botanic Gardens, Kew, pp. 97-112.

Abu-Asab, M.S., Cantino, P.D., 1993. Systematic implications of pollen morphology in Caryopteris (Labiatae). Systematic Botany 18, 502-515.

Abu-Asab, M.S., Cantino, P.D., 1994. Systematic implications of pollen morphology in subfamilies Lamioideae and Pogostemonoideae (Labiatae). Annals of the Missouri Botanical Garden 81, 653-686.
Bentham, G., 1848. Labiatae. In: de Candolle, A.P. (Ed.), Prodromus systematis Universalis Regni Vegetabilis, vol. 12. Treuttel et Würtz, Paris, pp. 212-226. Bräuchler, C., Meimber, H., Abele, T., Heubl, G., 2005. Polyphyly of the genus Micromeria (Lamiaceae) - evidence from cpDNA sequence data. Taxon 54, 639-650.

Briquet, J., 1897. Labiatae. In: Engler, A., Prantl, K. (Eds.), Die naturlichen pflanzenfamilien nebst ihrer Gattungen und wichtigeren Arten, vol. IV. Wilhelm Engelmann, Leipzig, pp. 183-287.

Bronckers, F., 1963. Variations polliniques dans une série d'autopolyploïdes artificiels d'Arabidopsis thaliana. (L.) Heynh. Pollen et Spores 5, 233-238.

Budantsev, A.L., 1987. The system of the genus Dracocephalum (Lamiaceae). Botanicheskii Zhurnal 72, 260-267 (in Russian).

Budantsev, A.L., 1992a. The system of synopsis of the genus Lophanthus (Lamiaceae). Botanicheskii Zhurnal 77, 69-77 (in Russian). 
Budantsev, A.L., 1992b. A synopsis of the tribe Nepeteae (Lamiaceae) - the genera Meehania, Glechoma, Drepanocaryum, Marmoritis and Hymenocrater. Botanicheskii Zhurnal 77, 118-128 (in Russian).

Budantsev, A.L., 1993a. A synopsis of the genus Nepeta (Lamiaceae). Botanicheskii Zhurnal 78, 93-107 (in Russian).

Budantsev, A.L., 1993b. A synopsis of the tribe Nepeteae (Lamiaceae) - the genera Lophanthus, Dracocephalum, Cedronella, Schizonepeta and Agastache. Botanicheskii Zhurnal 78, 106-115 (in Russian).

Budantsev, A.L., Lobova, T.A., 1997. Fruit morphology, anatomy and taxonomy of tribe Nepeteae (Labiatae). Edinburgh Journal of Botany 54, 183-216.

Cartier, D., 1971. Etude biosystématique de quelques espèces du genre Plantago (Thurn.) L. I. Historique, races chromosomiques du Plantago alpina L. et du Plantago serpentina All. Revue générale de Botanique 78, 493-556.

Cantino, P.D., 1992. Evidence for a polyphyletic origin of the Labiatae. Annals of the Missouri Botanical Garden 79, 361-379.

Dajoz, I., 1990. Polymorphisme pollinique chez le pollen et la fleur de Viola diversifolia (Gingins) Becker. Bulletin de la société botanique de France 137, Actualités botaniques 2, 148-150.

Demissew, S., Harley, M.M., 1992. Trichome, seed surface and pollen characters in Stachys (Labiatae) in Tropical Africa. In: Harley, R.M., Reynolds, T. (Eds.), Advances in Labiatae Science. Royal Botanic Gardens, Kew, pp. 149-166.

Erdtman, G., 1945. Pollen morphology and plant taxonomy. IV. Labiatae, Verbenaceae and Avicenniaceae. Svensk Botanisk Tidskrift 39, 279-285.

Erdtman, G., 1966. Pollen morphology and plant taxonomy. Hafner, New York, NY.

Furness, C.A., Rudall, P.J., 1998. The tapetum and systematics in monocotyledons. Botanical Review 64, 201-239.

Harley, M.M., 1992. The potential value of pollen morphology as an additional taxonomic character in subtribe Ociminae (Ocimeae: Nepetoidaea: Labiatae). In: Harley, R.M., Reynolds, T. (Eds.), Advances in Labiatae Science. Royal Botanic Gardens, Kew, pp. 125-138.

Harley, M.M., Paton, A., Harley, R.M., Cade, P.G., 1992. Pollen morphological studies in tribe Ocimeae (Nepetoidaea: Labiatae): I. Ocimum L. Grana 31, 161-176.

Harley, R.M., Atkins, S., Budantsev, A.L., Cantino, P.D., Conn, B.J., Grayer, R., Harley, M.M., De Kok, R., Krestovskaja, T., Morales, R., Paton, A.J., Ryding, O., Upson, T., 2004. Labiatae. In: Kadereit, J.W. (Ed.), The families and genera of vascular plants VII. Flowering plants Dicotyledons: Lamiales (except Acanthaceae including Avicenniaceae). Springer-Verlag, Berlin, pp. 167-275.

Holmgren, P.K., Holmgren, N.H., Barnett, L.C., 1990. Index herbariorum, part 1. The herbaria of the world, 8th edition. Regnum Vegetabile 120, 1-693.

Huysmans, S., El-Ghazaly, G., Smets, E., 1998. Orbicules in angiosperms: morphology, function, distribution, and relation with tapetum types. Botanical Review 64, 240-272.

Huysmans, S., El-Ghazaly, G., Smets, E., 2000. Orbicules: still a well hidden secret of the anther. In: Nordenstam, B., El-Ghazaly, G., Kassas, M. (Eds.), Plant Systematics for the 21st Century. Wenner-Gren International Series, vol. 77. Portland Press, London, pp. 201-212.

Jamzad, Z., Chase, M.W., Ingrouille, M., Simmonds, M.S.J., Jalili, A., 2003. Phylogenetic relationships in Nepeta L. (Lamiaceae) and related genera based on ITS sequence data. Taxon 52, 21-32.

Jamzad, Z., Harley, M.M., Ingrouille, M., Simmonds, M.S.J., Jalili, A., 2000. Pollen exine and nutlet surface morphology of the annual species of Nepeta L. (Lamiaceae) in Iran. In: Harley, M.M., Morton, G.M., Blackmore, S. (Eds.), Pollen and Spores: Morphology and Biology. Royal Botanic Gardens, Kew, pp. 385-397.

Kessler, L.G., Larson, D.A., 1969. Effects of polyploidy on pollen grain diameter and other exomorphic exine features in Tridax coronifolia. Pollen et Spores 11, 203-221.

Lens, F., Dressler, S., Vinckier, S., Janssens, S., Dessein, S., Van Evelghem, L., Smets, E., 2005. Palynological variation in Balsaminoid Ericales. I. Marcgraviaceae. Annals of Botany 96, 1047-1060.

Levin, E.G., 1941. The genus Lophanthus and its analogon Pseudolophanthus. Trudy Botanicheskogo Instituta Akademii Nauk SSSR. Ser.1. 5, pp. 256-318 (in Russian).
Lint, H., Epling, C., 1945. A revision of Agastache. American Midland Naturalist 33, 207-230.

Mignot, A., Hoss, C., Dajoz, I., Leuret, C., Henry, J.P., Druillaux, J.M., HeberleBors, E., Till-Bottraud, I., 1994. Pollen aperture polymorphism in the Angiosperms; importance, possible causes and consequences. Acta Botanica Gallica 141, 109-122.

Moon, H.K., Hong, S.P., 2003. Pollen morphology of the genus Lycopus (Lamiaceae). Annales Botanici Fennici 40, 191-198.

Moon, H.K., Vinckier, S., Walker, J.B., Smets, E., Huysmans, S., in press. A search for phylogenetically informative pollen characters in the subtribe Salviinae (Mentheae: Lamiaceae). International Journal of Plant Sciences. doi: $10.1086 / 526463$.

Nabli, M.A., 1976. Etude ultrastructurale comparee de l'exine chez quelques genres de Labiatae. In: Ferguson, I.K., Muller, J. (Eds.), The evolutionary significance of the exine. Academy Press, London, pp. 499-525.

Pojarkova, A.I., 1954. Nepetinae. In: Shishkin, B.K. (Ed.), Flora of the U.S.S.R., vol. 20. Izdatel'stvo Akademii Nauk SSR, Labiatae, Moscow, USSR, pp. 273-492.

Punt, W., Hoen, P.P., Blackmore, S., Nilsson, S., Le Thomas, A., 2007. Glossary of pollen and spore terminology. Review of Palaeobotany and Palynology 143, 1-81.

Raj, B., El-Ghazaly, G., 1987. Morphology and taxonomic application of orbicules (Ubisch bodies) in Chloanthaceae. Pollen et Spores 29, 151-166.

Reitsma, T., 1969. Size modifications of recent pollen under treatments. Review of Palaeobotany and Palynology 9, 175-202.

Sanders, R.W., 1987. Taxonomy of Agastache section Brittonastrum (Lamiaceae-Nepeteae). Systematic Botany monographs 15, 1-92.

Schols, P., Dessein, S., D’Hondt, C., Huysmans, S., Smets, E., 2002. Carnoy: a new digital measurement tool for palynology. Grana 41, 124-126.

Schols, P., Es, K., D’hondt, C., Merchx, V., Smets, E., Huysmans, S., 2004. A new enzyme-based method for the treatment of fragile pollen grains collected from herbarium material. Taxon 53, 777-782.

Suarez-Cervera, M., Seoane-Camba, J.A., 1986. Ontogénèse des grains de pollen de Lavandula dentata L. et évolution des cellules tapétales. Pollen et Spores 28, 5-28.

Till-Bottraud, I., De Paepe, R., Mignot, A., Dajoz, I., 1995. Pollen heteromorphism in Nicotiana tabacum (Solanaceae). American Journal of Botany 82, 1040-1048.

Till-Bottraud, I., Venable, D.L., Dajoz, I., Gouyon, P.H., 1994. Evolution of pollen morphology: a game theory model. American Naturalist 144, 395-411.

Trudel, M.C., Morton, J.K., 1992. Pollen morphology and taxonomy in North American Labiatae. Canadian Journal of Botany 70, 975-995.

Varghese, T.M., Verma, D.P.S., 1968. Pollen morphology of some Indian Labiatae. Journal of Palynology 4, 77-83.

Vij, S.P., Kashyap, S.K., 1975. Pollen grain studies in some Labiatae. Journal of Palynology 11, 29-42.

Wagstaff, S.J., 1992. A phylogenetic interpretation of pollen morphology in tribe Mentheae (Labiatae). In: Harley, R.M., Reynolds, T. (Eds.), Advances in Labiatae Science. Royal Botanic Gardens, Kew, pp. 113-124.

Wagstaff, S.J., Olmstead, R.G., Cantino, P.D., 1995. Parsimony analysis of cpDNA restriction site variation in subfamily Nepetoideae (Labiatae). American Journal of Botany 82, 886-892.

Walker, J.B., Sytsma, K.J., Treutlein, J., Wink, M., 2004. Salvia (Lamiaceae) is not monophyletic: implications for the systematics, radiation, and ecological specializations of Salvia and tribe Mentheae. American Journal of Botany 91, 1115-1125.

Walker, J.B., Sytsma, K.J., 2007. Staminal evolution in the genus Salvia (Lamiaceae): Molecular phylogenetic evidence for multiple origins of the staminal lever. Annals of Botany 100, 375-391.

Waterman, A.H., 1960. Pollen grain studies of the Labiatae in Michigan. Webbia $15,399-415$

Wunderlich, R., 1967. Ein Vorschlag zu einer natürlichen Gliederung der Labiaten auf Grund der Pollenkörner, der Samenentwicklung und des reifen Samens. Oesterreichische Botanische Zeitschrift 114, 383-483. 